\title{
Estimasi Parameter pada Model Poisson Generalized Autoregressive Moving Average (GARMA) dengan Algoritma IRLS Studi Kasus: Peramalan Jumlah Kecelakaan di Jalan Tol Surabaya-Gempol
}

\author{
Agil Desti Fauzia dan Laksmi Prita Wardhani \\ Departemen Matematika, Fakultas Matematika Komputasi dan Sains Data, \\ Institut Teknologi Sepuluh Nopember (ITS) \\ e-mail: laksmiprita61@gmail.com
}

\begin{abstract}
Abstrak-Peramalan adalah pengolahan data masa lalu untuk mendapatkan estimasi data masa depan. Data yang digunakan pada penelitian ini adalah data count. Pada kasus data count metode peramalan pada umumnya seperti ARIMA kurang tepat digunakan. Benjamin, dkk. mengembangkan sebuah model peramalan yaitu Generalized Autoregessive Moving Average (GARMA) dengan menggunakan fungsi penghubung (link function) dengan data diasumsikan mengikuti Distribusi Poisson sehingga disebut juga Poisson GARMA $(p, q)$. Pada model tersebut terdapat beberapa parameter yang tidak diketahui. Parameter yang dimaksud diestimasi menggunakan metode Maximum Likelihood Estimation (MLE) dengan optimasi Algoritma Iteratively Reweighted Least Squares (IRLS). Model Poisson GARMA ini diterapkan pada data jumlah kejadian kecelakaan di jalan tol Surabaya-Gempol ruas WaruSidoarjo. Hasil yang didapat yaitu model khusus Poisson GARMA $(1,1)$ dengan 3 parameter yaitu parameter konstanta $\left(\beta_{0}\right)$, Autoregressive $(\phi)$, dan Moving Average $(\theta)$. Kriteria pemilihan model terbaik menggunakan AIC.
\end{abstract}

Kata Kunci-Data count, Distribusi Poisson, Fungsi Link, Poisson GARMA $(p, q)$, Algoritma IRLS.

\section{PENDAHULUAN}

$\mathrm{M}$ ETODE time series adalah metode peramalan dengan menggunakan analisa plot hubungan antara variabel yang akan diperkirakan dengan variabel waktu. Peramalan adalah pengolahan data masa lalu untuk mendapatkan estimasi data masa depan atau yang akan datang. Terdapat beberapa jenis data yang dikenal seperti nominal, ordinal, interval, dan juga data hitung (count). Untuk data hitung biasanya ditemukan pada suatu kasus atau pada sampel percobaan. Data jenis ini paling sering menyebabkan data tidak menyebar normal [1]. Untuk mengatasi hal tersebut, kajian pemodelan peramalan runtun waktu dikembangkan dan salah satunya diterapkan pada data deret hitung (count). Contoh data deret hitung (count) yang sering ditemui antara lain: jumlah kecelakaan di jalan raya yang terjadi dalam sebulan, jumlah anak ikan yang menetas pada perlakuan khusus di laboratorium, jumlah pertandingan sepakbola yang tertunda karena hujan pada satu musim liga, jumlah serangan hama pada 1 hektar sawah, dan lain-lain [2].

Benjamin, dkk. mengembangkan model Generalized Autoregressive Moving Average (GARMA) untuk data-data yang mengikuti distribusi non-Gaussian seperti Distribusi
Poisson [3]. Model GARMA merupakan pengembangan dari perluasan Generalize Linier Models (GLM) dimana model GARMA menghubungkan komponen ARMA dengan variabel prediktor ke transformasi parameter rata-rata dari distribusi data dengan menggunakan fungsi link . Fungsi link ini digunakan untuk memastikan bahwa distribusi data tetap dalam domain bilangan riil positif, sehingga memiliki ketepatan prediksi yang lebih akurat [4]. Pada penelitian ini dilakukan estimasi mengenai model GARMA dimana data yang digunakan diasumsikan mengikuti distribusi Poisson atau disebut Poisson GARMA $(p, q)$ dengan studi kasus yaitu data jumlah kecelakaan di jalan tol Surabaya-Gempol ruas Waru-Sidoarjo dalam batasan waktu tertentu.

\section{TINJAUAN PUSTAKA}

\section{A. Model ARMA}

Model Autoregressive Moving Average (ARMA) merupakan model ARIMA tanpa proses pembedaan atau ARIMA $(p, 0, q)$. Secara matematis model ARMA $(p, q)$ ditulis sebagai berikut:

$$
Y_{t}=\phi_{1} X_{t-1}+\ldots+\phi_{p} X_{t-p}+e_{t}-\theta_{1} e_{t-1}-\ldots-\theta_{q} e_{t-q}
$$

dengan:

$\phi_{1}$ : Parameter Autoregressive

$\theta_{1}$ : Parameter Moving Average

\section{B. Model Poisson Data Count}

Distribusi bersyarat dari hasil observasi $y_{t}$, untuk $t=$ $1,2,3, \ldots, n$ diberikan pada himpunan $H_{t}=$ $\left\{x_{t}, \ldots, x_{1}, y_{t-1}, \ldots, y_{1}, \mu_{t-1}, \ldots, \mu_{1}\right\}$, yang merupakan keluarga eksponensial. Fungsi kepadatan peluang dari distribusi Poisson sebagai berikut:

$$
f(x ; \mu)=\frac{e^{-\mu_{t}} \mu^{y t}}{y_{t} !} \quad ; y=0,1,2, \ldots, n
$$

dengan:

$$
\begin{aligned}
& y_{t}=0,1,2, \ldots \\
& t=1,2,3, \ldots, n \\
& E\left(Y_{t}\right)=\mu_{t} \\
& \operatorname{Var}\left[Y_{t}\right]=\mu_{t}
\end{aligned}
$$

Model Poisson diperoleh dari bentuk eksponensial dari distribusi Poisson yaitu sebagai berikut:

$$
f\left(y_{t} ; \beta \mid H_{t-1}\right)=\exp \left\{y_{t} \ln \mu_{t}-\mu_{t}-\ln y_{t} !\right\}
$$


untuk $=1,2, \ldots, n ; E\left(Y_{t} \mid H_{t-1}\right)=\mu_{t} ; b\left(\theta_{t}\right)=\mu_{t}=\exp \left(\theta_{t}\right)$ $; \operatorname{Var}\left(\mu_{t}\right)=\mu_{t}$ dan $\omega_{t}=1$ dengan bentuk link kanonik :

$$
\left(\mu_{t}\right)=\theta_{t}=\ln \mu_{t}=\eta_{t}
$$

dan $\eta_{t}=\boldsymbol{Z}_{t-1}^{\prime} \boldsymbol{\beta}, \quad \boldsymbol{\beta}$ merupakan parameter yang tidak diketahui.

\section{Model GARMA}

Model GARMA dikenalkan pertama kali oleh Benjamin, dkk. Yairu sebagai berikut[3]:

$$
g(\mu)=\boldsymbol{Z}_{t-1}^{T} \boldsymbol{\beta}=\boldsymbol{X}_{t-1}^{T} \boldsymbol{\beta}+\tau_{t}
$$

dengan

$$
\tau_{t}=\sum_{j=1}^{p} \phi_{j} \mathcal{A}\left(y_{t-j}, x_{t-j}, \beta\right)+\sum_{j=1}^{q} \phi_{j} \mathcal{M}\left(y_{t-j}, \mu_{t-j}\right)
$$

$\tau_{t}$ :komponen AR dan MA

$A$ :fungsi yang mempresentasikan bentuk autoregressive

$\mathcal{M}$ :fungsi yang mempresentasikan bentuk moving average $\phi^{T}$ :parameter autoregressive ;

$\phi^{T}=\left(\phi_{1}, \phi_{2}, \ldots, \phi_{p}\right)$

$\theta^{T}$ :parameter moving average ;

$\boldsymbol{\theta}^{T}=\left(\theta_{1}, \theta_{2}, \ldots, \theta_{p}\right)$

Bentuk sub model parsimoni dari model GARMA $(p, q)$ yang didefinikan oleh Benjamin, dkk.(2003) adalah sebagai berikut :

$$
\begin{aligned}
g(\mu)=\boldsymbol{Z}_{t-1}^{T} \boldsymbol{\beta} & p \\
g(\mu)=\boldsymbol{X}_{t-1}^{T} \boldsymbol{\beta} & +\sum_{j=1}^{p} \phi_{j}\left\{g\left(y_{t-j}\right)-X_{t-j}^{T} \beta\right\} \\
& +\sum_{j=1}^{q} \phi_{j}\left\{g\left(y_{t-j}\right)-\eta_{t-j} \beta\right\}
\end{aligned}
$$

\section{Poisson GARMA $(p, q)$}

Model Poisson GARMA $(p, q)$ dikembangkan berdasarkan model GARMA $(p, q)$ dengan asumsi data berdistribusi Poisson. Diberikan $y^{T}=$ $\left(y_{t}, y_{t+1}, \ldots, y_{t+n}\right)$ adalah model data deret waktu. Jika $y_{t} \sim \operatorname{Poisson}\left(\mu_{t}, \alpha\right)$ maka $E\left(y_{t}\right)=\operatorname{Var}\left(y_{t}\right)=\mu_{t}$ dan $\alpha \rightarrow$ 0 . Jika $g$ adalah fungsi logaritma natural (7) maka:

$$
\begin{aligned}
\ln (\mu)=\boldsymbol{X}_{t-1}^{T} \boldsymbol{\beta}+ & \sum_{j=1}^{p} \phi_{j}\left\{\ln y_{t-j}^{*}-\boldsymbol{X}_{t-j}^{T} \boldsymbol{\beta}\right\} \\
& +\sum_{j=1}^{q} \phi_{j}\left\{\frac{\ln y_{t-j}^{*}}{\mu_{t-j}}\right\}
\end{aligned}
$$

dimana $y_{t-j}^{*}=\max \left(y_{t-j}, c\right)$ dan $0<c \leq 1$. Jika terdapat nilai 0 pada nilai $y_{t-j}$ maka akan diganti dengan $c$ [3].

\section{E. Maximum Likelihood Estimation (MLE)}

Metode Maximum Likelihood Estimation adalah metode pendugaan yang memaksimumkan fungsi likelihood [5]. Dalam penelitian ini metode MLE digunakan untuk menduga parameter Poisson GARMA. Adapun fungsi Likelihood $L(\theta)$ sebagai berikut

$$
L(\theta)=\prod_{t=1}^{n} f\left(x_{i} \mid \theta\right)
$$

Untuk mempermudah perhitungan secara matematis, umumnya digunakan fungsi log-likelihoood.

$$
l(\theta)=\ln L(\theta)=\sum_{i=1}^{n} \ln f\left(x_{i} \mid \theta\right)
$$

Syarat cukup agar fungsi dari partial log-likelihood maksimum adalah :

$$
\frac{\partial l\left(\mu_{t}\right)}{\partial \beta_{0}}=0 ; \quad \frac{\partial l\left(\mu_{t}\right)}{\partial \phi_{j}}=0 ; \quad \frac{\partial l\left(\mu_{t}\right)}{\partial \theta_{j}}=0
$$

Karena ketika digunakan metode MLE masih menghasilkan bentuk close form maka dilanjutkan dengan iterasi numerik yaitu dengan optimasi menggunakan Algoritma IRLS.

\section{F. Algoritma Iteratively Reweighted Least Square (IRLS)}

Adapun langkah-langkah algoritma IRLS untuk mendapatkan taksiran parameter persamaan (8) adalah sebagai berikut [6].

1. Inisialisasi, memilih nilai awal untuk $\hat{\beta}_{(0)}$ dengan menggunakan metode Ordinary Least Square (OLS) untuk $t=2,3,4 \ldots, T$.

$$
\hat{\beta}_{(0)}=\left(x^{T} x\right)^{-1}\left(x^{T} y_{t}^{*}\right)
$$

$x$ dan $y$ didefinisikan sebagai berikut :

$$
x=\left[\begin{array}{cccc}
1 & x_{11} & \ldots & x_{k 1} \\
1 & x_{12} & \ldots & x_{k 2} \\
\vdots & \vdots & \ddots & \vdots \\
1 & x_{1 n} & \ldots & x_{k n}
\end{array}\right] \text { dan } y=\left[\begin{array}{c}
\ln y_{1}^{*} \\
\ln y_{2}^{*} \\
\vdots \\
\ln y_{T-1}^{*}
\end{array}\right]
$$

2. Menghitung nilai $\widehat{\boldsymbol{\mu}}^{(\mathbf{0})}$

$$
\begin{gathered}
\widehat{\boldsymbol{\mu}}^{(\mathbf{0})}=\exp \left(\boldsymbol{X}_{\boldsymbol{t}}^{\boldsymbol{T}} \boldsymbol{\beta}\right) \\
\widehat{\boldsymbol{\mu}}^{(\mathbf{0})}=\hat{\beta}_{(0)}^{(0)}+\hat{\beta}_{(1)}^{(0)} \ln y_{t-1}^{*}
\end{gathered}
$$

3. Menghitung nilai $W$

$$
W^{(1)}=\left[\begin{array}{llll}
\frac{1}{\widehat{\boldsymbol{\mu}}_{\mathbf{0}}{ }^{(\mathbf{0})}} & & & \\
& \frac{1}{\widehat{\boldsymbol{\mu}}_{\mathbf{1}}{ }^{(\mathbf{0})}} & & \\
& & \ddots & \\
& & & \frac{1}{\widehat{\boldsymbol{\mu}}_{T-\mathbf{1}}{ }^{(\mathbf{0})}}
\end{array}\right]
$$

4. Menghitung nilai $z$ yakni sebagai berikut :

$$
\begin{gathered}
z^{(1)}=\boldsymbol{\eta}_{t}^{(1)}+\frac{y_{t}+\widehat{\boldsymbol{\mu}}_{\mathbf{0}}}{\widehat{\boldsymbol{\mu}}_{\mathbf{0}}} \\
\boldsymbol{\eta}_{t}^{(1)}=\boldsymbol{X} \hat{\beta}^{(1)}
\end{gathered}
$$

5. Menghitung estimasi

$$
\widehat{\boldsymbol{\beta}}^{(k+1)}=\left(\boldsymbol{X}^{\boldsymbol{T}} \boldsymbol{W}^{(\boldsymbol{k}+\mathbf{1})} \boldsymbol{X}\right)^{-1} \boldsymbol{X}^{\boldsymbol{T}} \boldsymbol{W}^{(\boldsymbol{k}+\mathbf{1})} Z^{(k+1)}
$$

6. Ulangi langkah sampai dengan e menggunakan nilai $\widehat{\boldsymbol{\beta}}^{(\mathbf{1})}$ sehingga akan diperoleh nilai baru $\widehat{\boldsymbol{\beta}}^{(2)}$

7. Update $k$ ke $k+1$ dan ulangi langkah b sampai diperoleh toleransi sebagai berikut :

$$
\left|\hat{\beta}^{(t)}-\hat{\beta}^{(t-1)}\right|<\varepsilon_{\beta}
$$

\section{METODOLOGI PENELITIAN}

Pada penelitian ini, data yang digunakan adalah data jumlah kejadian kecelakaan di jalan Tol Surabaya-Gempol ruas Waru-Sidoarjo dari bulan Januari tahun 2012 hingga Agustus tahun 2017 dengan jumlah data sebesar 68. Data tersebut diperoleh dari pihak pengelola jalan tol P.T. Jasa Marga Variabel $\mathrm{Y}$ yang digunakan dalam penelitian ini 
adalah jumlah kecelakaan di jalan Tol Surabaya-Gempol ruas Waru-Sidoarjo.

Table 1.

Variabel Penelitian

\begin{tabular}{|c|c|c|}
\hline Tahun & Bulan & Jumlah Kecelakaan (Y) \\
\hline \multirow{3}{*}{2012} & Januari & $Y_{1}$ \\
\hline & Februari & $Y_{2}$ \\
\hline & $\vdots$ & $\vdots$ \\
\hline \multirow{3}{*}{2013} & Desember & $Y_{12}$ \\
\hline & Januari & $Y_{13}$ \\
\hline & Februari & $Y_{14}$ \\
\hline \multirow{7}{*}{$2017^{\vdots}$} & $\vdots$ & $\vdots$ \\
\hline & Desember & $Y_{24}$ \\
\hline & $\vdots$ & $\vdots$ \\
\hline & Januari & $Y_{61}$ \\
\hline & Februari & $Y_{62}$ \\
\hline & $\vdots$ & \\
\hline & Agustus & $Y_{68}$ \\
\hline
\end{tabular}

Langkah-langkah analisis yang digunakan untuk mencapai tujuan penelitian yakni sebagai berikut:

1. Pengumpulan data

Pada tahap ini dilakukan pengumpulan data jumlah kecelakaan di jalan Tol Surabaya-Gempol ruas WaruSidoarjo dari P.T. Jasa Marga.

2. Studi Literatur

Pada tahap ini dilakukan studi literatur untuk mendukung penelitian. Bahan-bahan referensi yang digunakan berupa buku, jurnal, tugas akhir, thesis dan juga media elektronik (internet) yang sesuai dan berhubungan dengan permasalahan yang dibahas.

3. Mengkaji cara mendapatkan penaksir parameter model Poisson GARMA $(p, q)$ menggunakan metode MLE dengan optimasi Algoritma IRLS.

4. Melakukan peramalan model Poisson GARMA $(p, q)$ pada data jumlah kecelakaan di jalan tol SurabayaGempol ruas Waru-Sidoarjo.

\section{ANALISA DAN PEMABAHASAN}

\section{A. Estimasi Parameter Model Poisson GARMA $(p, q)$}

Pada penelitian ini, variabel prediktor $x$ diabaikan sehingga menurut Marinho dan Ricardo (2015) $X_{t-1}^{T} \beta$ dapat diganti dengan suatu konstanta $\beta_{0}$. Sehingga persamaan menjadi:

$$
\ln \left(\mu_{t}\right)=\beta_{0}+\sum_{j=1}^{p} \phi_{j}\left\{\ln y_{t-j}^{*}\right\}+\sum_{j=1}^{q} \theta_{j}\left\{\frac{\ln y_{t-j}^{*}}{\mu_{t-j}}\right\}
$$

dimana $y_{t-j}^{*}=\max \left(y_{t-j}, c\right)$ dan $0<c \leq 1$.

Jika persamaan dibentuk kedalam matriks, maka bentuk matrik sebagai berikut:

$$
\left[\begin{array}{c}
\ln \left(\mu_{1}\right) \\
\ln \left(\mu_{2}\right) \\
\ln \left(\mu_{3}\right) \\
\vdots \\
\ln \left(\mu_{T}\right)
\end{array}\right]=\left[\begin{array}{ccccccc}
1 & \ln y_{1}^{*} & \ldots & \ln y_{1}^{*} & \ln \frac{y_{1}^{*}}{\mu_{1}} & \ldots & \ln \frac{y_{1}^{*}}{\mu_{1}} \\
1 & \ln y_{2}^{*} & \ldots & \ln y_{2}^{*} & \ln \frac{y_{2}^{*}}{\mu_{2}} & \ldots & \ln \frac{y_{2}^{*}}{\mu_{2}} \\
1 & \vdots & \vdots & \vdots & \vdots & \vdots & \vdots \\
1 & \ln y_{T-1}^{*} & \ldots & \ln y_{T-1}^{*} & \ln \frac{y_{T-1}^{*}}{\mu_{T-1}} & \ldots & \ln \frac{y_{T-1}^{*}}{\mu_{T-1}}
\end{array}\right]\left[\begin{array}{c}
\beta_{0} \\
\phi_{1} \\
\vdots \\
\phi_{p} \\
\theta_{1} \\
\vdots \\
\theta_{q}
\end{array}\right]
$$

Sehingga diperoleh persamaan sebagai berikut :

$$
\begin{array}{r}
\mu_{t}=\exp \left[\beta_{0}+\sum_{j=1}^{p} \phi_{j}\left\{\ln y_{t-j}^{*}\right\}\right. \\
\left.+\sum_{j=1}^{q} \theta_{j}\left\{\frac{\ln y_{t-j}^{*}}{\mu_{t-j}}\right\}\right]
\end{array}
$$

Dalam mencari estimasi parameter model Poisson GARMA $(p, q)$ langkah awal yang dilakukan yaitu dengan mengasumsikan bahwa variabel respon $y$ pada data jumlahan mengikuti distribusi Poisson . Sesuai dengan persamaan (9) bentuk partial likelihood dari distribusi Poisson sebagai berikut:

$$
P L(\gamma)=\prod_{t=1}^{n} \frac{\exp \left(-\mu_{t}(\gamma)\right) \mu_{t}(\gamma)^{y_{t}}}{y_{t} !}
$$

persamaan diatas dibentuk kedalam partial log-slikelihood (10) sehingga diperoleh:

$$
\begin{aligned}
l(\gamma)=\sum_{t=1}^{n} y_{t} \ln \mu_{t}(\gamma) & \\
& -\sum_{t=1}^{n} \mu_{t}(\gamma)-\sum_{t=1}^{n}\left(y_{t} !\right)
\end{aligned}
$$

Persamaan (12) disubtitusikan kedalam persamaan (14) sehingga diperoleh persamaan baru sebagai berikut:

$$
\begin{aligned}
l(\gamma)=\sum_{t=1}^{n} y_{t} \ln \left\{\exp \left(\beta_{0}+\sum_{j=1}^{p} \phi_{j}\left\{\ln y_{t-j}^{*}\right\}+\sum_{j=1}^{q} \theta_{j}\left\{\frac{\ln y_{t-j}^{*}}{\mu_{t-j}}\right\}\right)\right\} \\
-\sum_{t=1}^{n}\left\{\operatorname { e x p } \left(\beta_{0}+\sum_{j=1}^{p} \phi_{j}\left\{\ln y_{t-j}^{*}\right\}(15)\right.\right. \\
\left.\left.+\sum_{j=1}^{q} \theta_{j}\left\{\frac{\ln y_{t-j}^{*}}{\mu_{t-j}}\right\}\right)\right\}-\sum_{t=1}^{n}\left(y_{t} !\right)
\end{aligned}
$$

Untuk memaksimumkan fungsi pada persamaan (15) maka dilakukan turunan pertama terhadap parameter. Misalkan parameter yang diestimasi adalah $\gamma=\left(\beta_{0}, \phi_{j}, \theta_{j}\right)$. Persamaan hasil turunan pertama tersebut tidak bisa diselesaikan secara analitik karena tidak memenuhi syarat cukup dari metode MLE sehingga untuk mengestimasi $\boldsymbol{\gamma}=$ $\left(\beta_{0}, \phi_{j}, \theta_{j}\right)$ digunakan optimasi algoritma Iteratively Reweighted Least Square (IRLS). Iterasi yang dilakukan pada algoritma IRLS berhenti ketika didapatkan parameter yang konvergen.

A. Pemodelan Poisson GARMA $(p, q)$ terhadap Jumlah Kejadian Kecelakaan di Jalan Tol Surabaya-Gempol ruas Waru-Sidoarjo.

Dalam melakukan identifikasi model Poisson GARMA $(p, q)$ langkah yang dilakukan sama dengan identifikasi model ARIMA. Dengan kata lain model Poisson GARMA $(p, q)$ diperoleh berdasarkan model sementara ARIMA. Proses dari identifikasi model sebagai berikut:

Pada Gambar 1 terlihat bahwa data belum stasioner terhadap varians maupun mean. Stasioneritas data terhadap varian dilakukan dengan transformasi Box-Cox dimana dikatakan stasioner ketika nilai $=1$. Nilai $\lambda$ yang diperoleh dalam Box-Cox plot mempengaruhi formula transformasi yang digunakan untuk mengubah data asli menjadi transformasi agar menghasilkan nilai $\lambda=1$.

Terlihat pada Gambar 2 bahwa nilai $\lambda$ (round value) adalah 0.5 , sehingga perlu dilakukan transfromasi Box-Cox dengan formula $\sqrt{Y_{t}}$. berdasarkan tabel berikut:

Table 2 .

Transformasi Box-Cox

\begin{tabular}{cc}
\hline \hline Nilai $\lambda$ & Transformasi Box-Cox \\
\hline-1 & $1 / Y_{t}$ \\
-0.5 & $1 / \sqrt{Y_{t}}$ \\
0 & $\ln Y_{t}$ \\
0.5 & $\sqrt{Y_{t}}$ \\
1 & $Y_{t}$ \\
\hline \hline
\end{tabular}




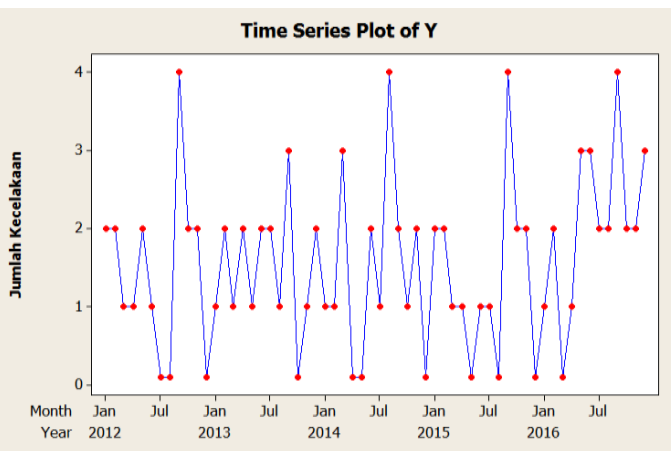

Gambar 1. Plot data time series jumlah kejadian kecelakaan.

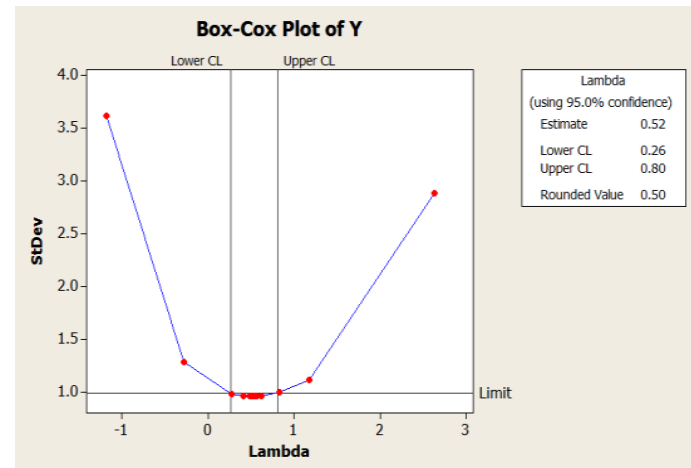

Gambar 2. Plot Transformasi Box-Cox.

Pada Gambar 3 terlihat hasil formula $\sqrt{Y_{t}}$ menghasilkan nilai $\lambda=1$ sehingga data telah stasioner terhadap varian. Selanjutnya stasioneritas data pada mean dapat dilihat dengan plot ACF dan PACF dari data hasil trnasformasi Box-Cox.

Dari Gambar 4 dan 5 mengidentifikasikan bahwa data sudah stasioner dalam mean. Hal ini terlihat dari plot ACF yang memiliki pola tentative karena tidak ada lag yang keluar dari significant limit. Dengan melihat gambar tersebut dapat dilakukan dugaan beberapa kemungkinan sementara model yang terbentuk. Model tersebut yaitu ARMA $(1,1)$, ARMA $(1,0)$, dan ARMA $(0,1)$.

Untuk mendapatkan model terbaik dilakukan uji signifikasi parameter dan uji diagnostik yang dilanjutkan dengan overfitting.

Table 3.

Overfitting Signifikasi Parameter

\begin{tabular}{ccc}
\hline \hline Model ARMA & Parameter & Keputusan \\
\hline$(1,1)$ & $\phi_{1}=0.8708$ & Signifikan \\
& $\theta_{1}=0.9613$ & Signifikan \\
$(1,0)$ & $\phi_{1}=-0.119$ & Tidak \\
& & Signifikan \\
$(0,1)$ & $\theta_{1}=0.01334$ & Tidak \\
& Signifikan \\
\hline \hline
\end{tabular}

Pada Tabel 3 terlihat bahwa diantara tiga model yang ada setelah melakukan proses overfitting, hanya satu model ARMA sementara yang memenuhi signifikasi dalam parameter, dengan syarat jika $\left|t_{\text {hitung }}\right|>t_{\text {tabel }}$ maka parameter dalam model signifikan sehingga satu model yang signifikan tersebut dilanjutkan pada pengujian diagnostik untuk menentukan model terbaik.

Table 4.

Uji Asumsi residual White Noise

\begin{tabular}{ccc}
\hline \hline Model ARMA & $D_{\text {hitung }}$ & Keputusan \\
\hline$(1,1)$ & 2.058 & Tidak Normal \\
\hline \hline
\end{tabular}

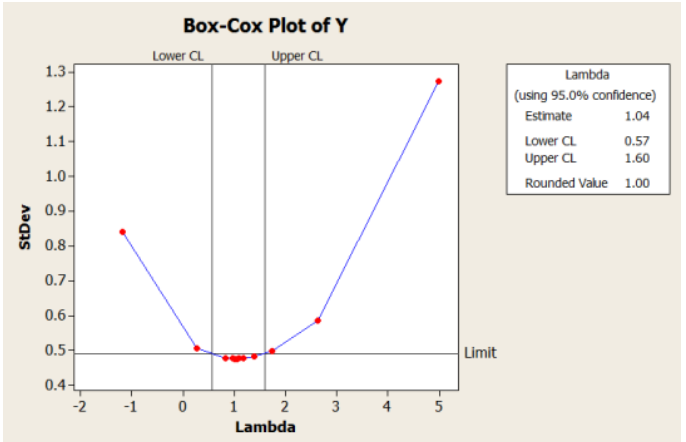

Gambar 3. Transformasi Box-Cox

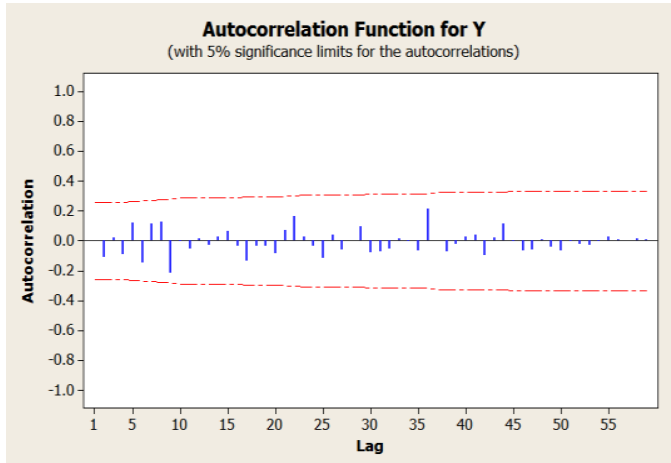

Gambar 4. Plot ACF Data Hasil Transformasi.

dari Tabel 4 diperoleh bahwa residual dalam model tersebut independen yaitu tidak saling berkolerasi.

Table 5 .

Uji Asumsi Normalitas

\begin{tabular}{cccc}
\hline \hline $\begin{array}{r}\text { Model } \\
\text { ARMA }\end{array}$ & $Q$ & $\chi^{2}$ & Keputusan \\
\hline$(1,1)$ & 9.67735 & 18.30704 & White Noise \\
\hline \hline
\end{tabular}

dari Tabel 5 diperoleh bahwa data juga tidak memenuhi asumsi normalitas karena nilai $D_{\text {hitung }}>D_{\text {tabel }}$ dengan nilai $D_{\text {tabel }}$ yaitu 2.058. Karena data tidak memenuhi asumsi residual berdistribusi normal amak dilakukan deteksi outlier. Hasil dari deteksi outlier pertama sudah menunjukkan bahwa residual berdistribusi normal yang dapat dilihat pada Gambar 6.

Sesuai dengan yang telah dijelaskan sebelumnya bahwa model Poisson GARMA $(p, q)$ diperoleh dari model sementara ARMA $(p, q)$. Model terbaik setelah dilakukan overfitting adalah ARMA $(1,1)$ yang berarti diperoleh model khusus Poisson GARMA $(1,1)$.

Dari model Poisson GARMA $(1,1)$ didapatkan estimasi parameter sebagai berikut:

\begin{tabular}{lc}
\hline \hline \multicolumn{1}{c}{ Parameter } & $S E$ \\
\hline$\beta_{0}=-5,627$ & 0,000 \\
$\phi_{1}=0,980$ & 0,000 \\
$\theta_{1}=-1,359$ & 0,097 \\
\hline \hline
\end{tabular}

Jadi diperoleh persamaan model Poisson GARMA $(1,1)$ untuk Jumlah Kejadian Kecelakaan di Jalan Tol SurabayaGempol Ruas Waru-Sidoarjo sebagai berikut:

$$
\left[\begin{array}{c}
\ln \left(\mu_{1}\right) \\
\ln \left(\mu_{2}\right) \\
\ln \left(\mu_{3}\right) \\
\vdots \\
\ln \left(\mu_{T}\right)
\end{array}\right]=\left[\begin{array}{ccc}
1 & \ln y_{0}^{*} & \ln y_{0}^{*} / \mu_{0} \\
1 & \ln y_{1}^{*} & \ln y_{1}^{*} / \mu_{1} \\
1 & \ln y_{2}^{*} & \ln y_{2}^{*} / \mu_{2} \\
\vdots & \vdots & \vdots \\
1 & \ln y_{T-1}^{*} & \ln y_{T-1}^{*} / \mu_{T-1}
\end{array}\right]\left[\begin{array}{c}
5,627 \\
0,980 \\
-1,359
\end{array}\right]
$$




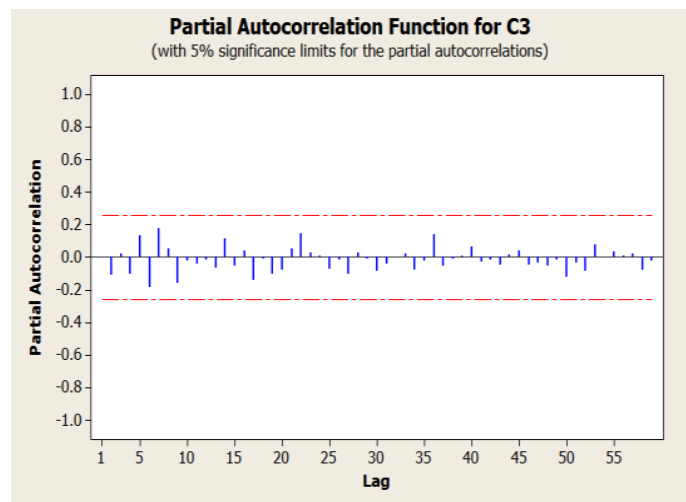

Gambar 5. Plot ACF Data Hasil Transformasi.

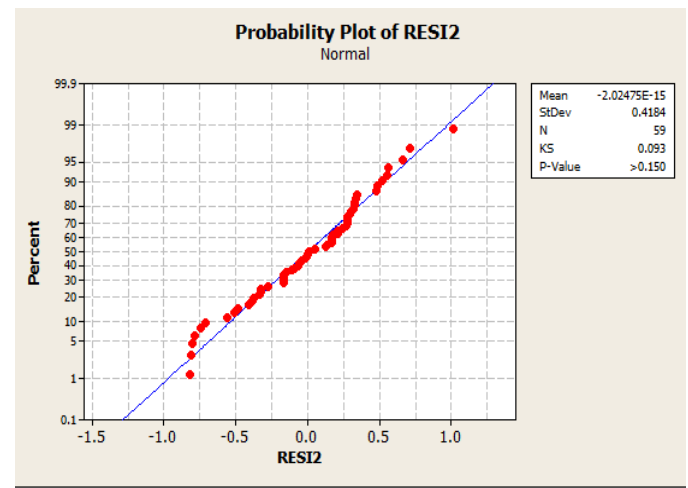

Gambar 6. Uji Normalitas ARMA (1,1) dengan Outlier.

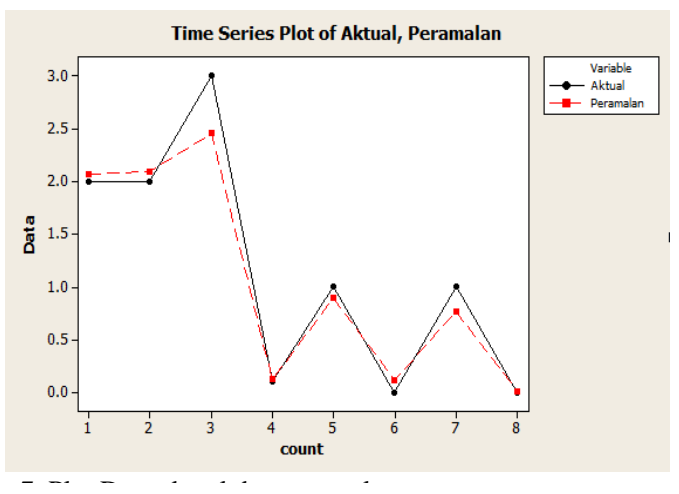

dengan persamaan model:

$\mu_{t}=\exp \left(5,627+0,980_{1}\left\{\ln y_{T-1}^{*}\right\}-1,359_{1}\left\{\ln \frac{y_{T-1}^{*}}{\mu_{T-1}}\right\}\right)$

model diatas digunakan untuk melakukan peramalan untuk 8 bulan kedepan.

A. Hasil Peramalan Data Jumlah Kejadian Kecelakaan di Jalan Tol Surabaya Gempol Ruas Waru-Sidoarjo dengan Poisson GARMA $(p, q)$

Peramalan model Poisson GARMA $(1,1)$ dilakukan dengan menggunakan software Matlab R2013a. Pada peramalan model Poisson GARMA ini digunakan 60 data sebagai in-sample dan 8 data sebagai out-sample. hasil peramalan dari data jumlah kecelakaan dijalan tol SurabayaGempol ruas Waru-Sidoarjo sebagai berikut :
Table 6

Hasil Peramalan Model Poisson GARMA $(1,1)$

\begin{tabular}{cc} 
Actual & Forecasting Poisson GARMA \\
\hline 2 & 2,067 \\
2 & 2,094 \\
3 & 2,456 \\
0 & 0,122 \\
1 & 0,892 \\
0 & 0,121 \\
1 & 0,77 \\
0 & 0,015
\end{tabular}

Dari hasil permalan diatas didapatkan nilai AIC dan Devian sebagai berikut :

$$
\begin{gathered}
A I C=763,900574, \\
\text { Devian }=12,932771
\end{gathered}
$$

Plot grafik hasil dari forecasting dengan data aktual dapat dilihat pada Gambar 7.

\section{KESIMPULAN}

Berdasarkan analisis dan pembahasan, dapat disimpulkan:

1. Estimasi parameter model Poisson GARMA $(p, q)$ dilakukan dengan menggunakan metode MLE karena diasumsikan mengikuti suatu distribusi eksponensial. karena metode MLE menghasilkan bentuk yang tidak close form dilakukan optimasi Algoritma IRLS sampai parameter tersebut konvergen. Algoritma IRLS untuk menentukan estimasi $\gamma$ sebagai berikut:

$$
\widehat{\boldsymbol{\gamma}}^{(k+1)}=\left(\boldsymbol{X}^{\boldsymbol{T}} \boldsymbol{W}^{(\boldsymbol{k}+\mathbf{1})} \boldsymbol{X}\right)^{-1} \boldsymbol{X}^{\boldsymbol{T}} \boldsymbol{W}^{(\boldsymbol{k}+\mathbf{1})} Z^{(k+1)}
$$

2. Hasil aplikasi Model Poisson GARMA yang diterapkan pada data jumlah kejadian kecelakaan dijalan Tol Surabaya-Gempol ruas Waru-Sidoarjo dibangun melalui identifikasi model terbaik ARMA yang kemudian diperoleh model Poisson GARMA $(1,1)$ dengan persamaan sebagai berikut:

$$
\mu_{t}=\exp \left(5,627+0,980_{1}\left\{\ln y_{T-1}^{*}\right\}-1,359_{1}\left\{\ln \frac{y_{T-1}^{*}}{\mu_{T-1}}\right\}\right)
$$

dengan hasil estimasi parameter yaitu parameter konstanta $\beta_{0}$ sebesar 5,627, parameter AR $\phi_{1}$ sebesar 0,980 , dan parameter $\theta_{1}$ sebesar 1,359 .

\section{DAFTAR PUSTAKA}

William W.S. Wei, Time Series Analysis: Univariate and Multivariate Methods, 2nd ed. Greg Tobin, 2006.

[2] A. Collin Cameron dan Pravin K. Trivedi, Regression Analysis of Count Data. New York, 1998.

[3] M. A. Benjamin, R. A. Rigby, D. M. Stasinopoulos, Journal of the American Statistical Association Generalized Autoregressive Moving Average Models Average Models,no. 2003.

[4] Asrirawan, Generalized Seosonal Autoregressive and Moving Average For Forecasting The Number of Dengue Hemorrhagic Fever (DHF) Patrient in Surabaya, 2014. [5] F. A. Widjajati, M. D. Saputri, dan N. Asiyah, "Sifat-Sifat Generalisasi Distribusi," no. 1, hal. 13-22, 1829.

[6] K. Fokianos dan B. Kedem, "Prediction and Classification of Nonstationary Categorical Time Series *," vol. 296, hal. 277-296, 1998. 